\title{
Dynamics of Poultry Production System, Constraints, Opportunities and Marketing in Ethiopia
}

\author{
Alemayehu Guteta \\ Ethiopia Institute of Agricultural Research,Bishoftu Agricultural Research Center, \\ P.O.Box 32, Bishoftu, Ethiopia
}

\begin{abstract}
The objectives this paper focuses on thedynamic ofpoultry production system constraints, opportunities and marketing system in the Ethiopia in the form of summary from past, recent and/or current studies. Currently, Ethiopia poultry production systems are classified into industrial and integrated/medium- and large-scale intensive systems and family poultry production systems (i.e. the small-scale intensive is characterized specialized, commercial day-old chicks (DOCs) or pullets (200-1 000 broilers, 100-500 layers), commercial balanced rations and good quality houses. semi-intensive is characterized by flocks ranging from 50 to 200 birds, using commercial, crossbred or indigenous breeds reared under scavenging management conditions with regular supplementation., extensive scavenging is characterized ranging from 5 to 50 birds comprised of indigenous and/or crossbred chickens and it is practiced by households having access to rural markets and small-extensive scavenging systemsit is based on a flock size of 1-5 indigenous chickens kept under scavenging conditions. The national average flock size of chicks, cockerels, pullet, hen, cocks, and total chicken per households were 5.3, $1.3,1.7,4,1.5$ and 11.1, respectively in Ethiopia. All scavenging chicken producer practice supplementary feeding $(100 \%)$ from all type of feed, supplemented maize account $(63 \%)$. It needs incorporate protein source feed at dry season.
\end{abstract}

Keywords: Production system, Ethiopia, chicken, productivity

DOI: $10.7176 / \mathrm{JMCR} / 77-01$

Publication date:March $31^{\text {st }} 2021$

\section{Introduction}

Ethiopia like in any other developing countries many rural households keep chicken in their farmyard. The total chicken population in the country is estimated to be 60.5 million of which $94.33 \%$ are the most dominant chicken types of the indigenous,3.21\% hybrid and $2.47 \%$ exotic (CSA, 2016). Chicken provides food and cash income and presents to strengthen social relationships and also play important socioeconomic roles in developing countries. (FOA, 2009, 2010). More than half of Ethiopian households both in rural and urban areas keep chickens, although there is considerable variation in the distribution of chicken keeping, with most households in highland areas are keeping chickens, and far fewer doing so in lowland pastoral areas (Ayele et al., 2009 and Wilson, 2010).

However, Ethiopian CSA (2013) reported that 96.9, 0.54 and $2.56 \%$ of the total poultry were reported to be indigenous, hybrid and exotic, respectively. The majority (99\%) of these chickens are maintained under a traditional system with little or no inputs for housing, feeding or health care. The most dominant chicken types reared in this system are local ecotypes, which show a large variation in body position, color, comb type and productivity (Tadelle et al., 2003b; Halima et al., 2007). The greater part of the feed for village chicken is obtained through scavenging, which includes the household cooking waste, cereal and cereal by-products, pulses, roots and tubers, oilseeds, shrubs, fruits and animal proteins (Samson and Endalew, 2010).

Rural poultry production suffers from the constraints of disease, insufficient feeding and lack of appropriate housing, inbreeding. If these constraints are removed, productivity would be increased to the direct benefit of the marginal farmer. Chicken mortality accounts for high losses in most production systems. Therefore, Developmental options for improving the productivity of indigenous chickens in the short term should be aiming at improving the basic managerial practices such as supplemental feeding, health care and providing shelter (Misba et al., 2011).

As number of scavenging chicken per household increased, income from chicken increased; also, fatherparticipation in labor division of chicken managementincreased but when number of chicken increased in each household, decision making for egg home consumption by father decreased, indicating that fathers transfer/share the responsibility with mother. (Alemayehu G. et.al 2020). Farmers who producedchicken under scavenging has the idea ofsupplementation feed for their chicken, however, the feedquality and quantities were inadequate as their contentswere majorly energy sources. Despite variations insource of water and frequency of watering, almost all ofthe respondents provided water for their chickensAlso, effort is needed tosolve the problem of feed quality along with price andsustainable market.

Therefore, the objective of this paper was, review the current situationof chicken production system,constraints opportunity and marketing and deliversensible findings information for beneficiaries. 


\section{Structure of the Ethiopian Poultry Production}

The poultry production systems of Ethiopia are classified into the industrial and integrated/medium- and largescale intensive systems and the different categories of family poultry production systems (i.e. the small-scale intensive, semi-intensive, extensive scavenging and small-extensive scavenging systems) (FAO, 2014). The classification based on some selected parameters such as location, farming system, breed, flock size, housing, feeding, health care, bio-security, access to vet. Services, rate of mortality and other technologies.Integrated/mediumand large-scale intensive producer's system keeping over 1000 broilers or 500 layers. Within such systems, there are large variations among producers in terms of technology use, management level and scale of operation.

Ethiopia livestock master plan 2015state that successful poultry interventions would allow the sub-sector to move to improved family poultry with semi- scavenging crossbreds and for substantial increases in the scale of specialized layer and broiler operations. Such a transformation would contribute considerably to reducing poverty and malnutrition among rural and urban poor, as well as increasing national income.Small-scale intensive and semi-intensive poultry production systems are found both in urban and rural areas. However, the former are mainly concentrated in urban and peri-urban areas in the central parts of the country. Such producers use different breeds of exotic and indigenous chicken and obtain inputs (e.g. day-old chicks of broilers and layers, pullets, feed and vaccines) from the medium- and large-scale intensive poultry producers in addition to a very limited supply from government sources particularly research centres. (FAO, 2019). The dominant proportion of the national poultry meat and eggs are produced under the scavenging family poultry production systems using low producing indigenous breeds. However, exotic breeds in intensive production systems are contributing to an increasing share of production. In 2016, exotic breeds contributed to more than 27 percent of the total number of eggs produced nationally, despite they constitute only 9 percent of the total national flock.

Table 1. Classification of Poultry Production Systems

\begin{tabular}{|c|c|c|c|c|c|}
\hline \multirow[t]{2}{*}{ Characteristics } & \multirow{2}{*}{$\begin{array}{l}\text { integrated } \\
\text { medium- and large- } \\
\text { scale intensive }\end{array}$} & \multicolumn{4}{|c|}{ Family poultry production systems } \\
\hline & & $\begin{array}{l}\text { Small-scale } \\
\text { intensive }\end{array}$ & Semi-intensive & $\begin{array}{l}\text { Extensive } \\
\text { scavenging }\end{array}$ & $\begin{array}{l}\text { Small-extensive } \\
\text { scavenging }\end{array}$ \\
\hline Location & $\begin{array}{l}\text { Peri-urban areas; } \\
\text { near capital \& major } \\
\text { cities }\end{array}$ & \multicolumn{2}{|c|}{ Peri-urban areas; near smaller towns } & \multicolumn{2}{|c|}{ Everywhere. Dominates in rural areas } \\
\hline $\begin{array}{l}\text { Production/ } \\
\text { farming } \\
\text { system }\end{array}$ & Poultry only & Poultry only & $\begin{array}{l}\text { Usually poultry } \\
\text { only } \quad \text { Usually } \\
\text { poultry only } \\
\end{array}$ & $\begin{array}{l}\text { Mixed, livestock } \\
\text { and crop mixed, } \\
\text { livestock \& crop }\end{array}$ & $\begin{array}{l}\text { Mixed, poultry } \\
\text { and crops, } \\
\text { often landless }\end{array}$ \\
\hline $\begin{array}{l}\text { Other livestock } \\
\text { raised }\end{array}$ & No & No & Sometimes & Usually & Rarely \\
\hline $\begin{array}{l}\text { Flock size } \\
\text { (adult birds) }\end{array}$ & $\begin{array}{l}>\quad 1000 \text { broilers } \\
>500 \text { layers }\end{array}$ & $\begin{array}{l}>200 \text { broilers } \\
>100 \text { layers }\end{array}$ & $50-200$ & $5-50$ & $1-5$ \\
\hline $\begin{array}{ll}\text { Access } & \text { to } \\
\text { markets } & \\
\end{array}$ & $\begin{array}{l}\text { Yes (export and } \\
\text { urban) }\end{array}$ & $\begin{array}{l}\text { Yes (urban } \\
\text { and rural) }\end{array}$ & $\begin{array}{l}\text { Yes (urban } \\
\text { and rural) }\end{array}$ & Limited (rural) & Rarely (rural) \\
\hline Poultry housing & $\begin{array}{l}\text { Yes; } \\
\text { conventional } \\
\text { materials; good- } \\
\text { quality houses }\end{array}$ & $\begin{array}{l}\text { Yes; } \\
\text { conventional } \\
\text { materials; } \\
\text { good-quality } \\
\text { houses }\end{array}$ & $\begin{array}{l}\text { Yes; conventional } \\
\text { materials; } \\
\text { of houses } \\
\text { qualities }\end{array}$ & $\begin{array}{l}\text { Sometimes; } \\
\text { usually made } \\
\text { from } \\
\text { materials }\end{array}$ & $\begin{array}{l}\text { Seldom; usually } \\
\text { made from local } \\
\text { materials or kept } \\
\text { in the house }\end{array}$ \\
\hline Poultry breeds & Commercial & Commercial & $\begin{array}{l}\text { Commercial, } \\
\text { crossbred or } \\
\text { indigenous }\end{array}$ & $\begin{array}{l}\text { Indigenous } \\
\text { crossbred }\end{array}$ & $\begin{array}{l}\text { Indigenous or } \\
\text { rarely crossbred }\end{array}$ \\
\hline $\begin{array}{l}\text { Source of new } \\
\text { chicks }\end{array}$ & $\begin{array}{l}\text { Commercial } \\
\text { day-old chicks } \\
\text { or pullets }\end{array}$ & $\begin{array}{l}\text { Commercial } \\
\text { day-old chicks } \\
\text { or pullets }\end{array}$ & $\begin{array}{l}\text { Commercial } \\
\text { day-old chicks or } \\
\text { natural incubation }\end{array}$ & $\begin{array}{l}\text { Natural } \\
\text { incubation }\end{array}$ & $\begin{array}{l}\text { Natural } \\
\text { incubation }\end{array}$ \\
\hline $\begin{array}{l}\text { Access to vet } \\
\text { services } \\
\text { veterinary } \\
\text { pharmaceutical }\end{array}$ & Yes & Yes & Yes & Sometimes & Rarely \\
\hline $\begin{array}{l}\text { Access to } \\
\text { conventional cold } \\
\text { chain }\end{array}$ & Yes & Yes & Yes & Rarely & No \\
\hline Poultry mortality & $\begin{array}{l}\text { Low to medium } \\
<20 \%\end{array}$ & $\begin{array}{l}\text { Low to medium }< \\
20 \%\end{array}$ & $\begin{array}{l}\text { Medium to high } 20 \\
\text { to }>50 \%\end{array}$ & very high $>70 \%$ & $\begin{array}{l}\text { Very } \\
>70 \%\end{array}$ \\
\hline $\begin{array}{l}\text { Food security of } \\
\text { owner }\end{array}$ & High & ok & ok & from ok to bad & from ok to bad \\
\hline
\end{tabular}

Sources: Adapted from FAO, 2014 and FAO biosecurity classification 


\section{Family poultry production systems}

Small-scale intensive poultry production system, is based on the use of specialized, commercial day-old chicks (DOCs) or pullets (200-1 000 broilers, 100-500 layers), commercial balanced rations and good quality houses. Producers under this system have full access to veterinary services and the overall mortality rates of birds are low to medium $(<20$ percent). The small-scale intensive system is rapidly growing in the urban and periurban areas of the country. They are mostly run as family businesses and considered as important sources of income for many families. Small-scale intensive poultry production currently plays a significant role in the employment of youth.(FAO, 2019).

Semi-intensivepoultry production system, is characterized by flocks ranging from 50 to 200 birds, using commercial, crossbred or indigenous breeds reared under scavenging managementconditions with regular supplementation. Differently from scavenging systems, birds are provided with housing and improved health care, resulting in low to medium mortality rates (from 20 to $>50$ percent)(FAO, 2019). The Ethiopian Livestock Master Plan (LMP) estimated that there were about 120000 households under the semi-intensive family poultry system in 2014 (Shapiro et al., 2015). However, the CSA report shows that the number of chicken holders with flock sizes ranging from 50 to 199 is only about 9 000, of which around 8000 holding from 50 to 99 chickens (CSA, 2017).

Extensive scavenging system, shares almost all the attributes described below for small extensive system. However, it is based on a larger flock size (ranging from 5 to 50 birds) comprised of indigenous and/or crossbred chickens and it is practiced by households having access to rural markets. Producers in this system do not have regular access to exotic chickensand usually raise their own replacement stock. Food security and income generation are the primary reasons for keeping chickens. They use broody hens to hatch replacement stock(FAO, 2019).

Small-extensive scavenging system, ispracticed by households located in remote villageswith little or no access to markets, with the main purpose of chicken rearing being for household consumption. It is based on a flock size of 1-5 indigenous chickens kept under scavenging conditions. Birds have no or little supplementary feeding and no housing. Chicksare produced through natural incubation. This system is also characterized by high chicken mortality (often $>70$ percent) due to lack of proper health care and veterinary services(FAO, 2019).

\section{Production and Productivity Performance of Chicken Indigenous chickenproduction in Ethiopia}

In 2016, indigenous chickens represented about 91 percent of the total national poultry population. (FAO, 2019). The importance of village poultry production in the national economy of developing countries and its role in improving the nutritional status and incomes of many small farmers and landless communities has been recognized by various scholars and rural development agencies for the last few decades (Abera and Tegene, 2011; Fissehaet al., 2010a). The indigenous chicken always fetches better price than exotics because of its taste and flavor. Ethiopia has a wealth of indigenous chicken genetic resources with unique meat and/or egg qualities, a low susceptibility to stress and other useful characteristics. Considerable variation in genetic and morphology of indigenous chickens in Ethiopia is potential resource for improvements.(Mammo and Tsega, 2011) Village based chicken production requires less space and investment and can therefore play an important role in improving the livelihood of the poor village family (Samson and Endalew, 2010).The average of egg production potential of scavenging chicken is $76.3 \mathrm{eggs} / \mathrm{year} / \mathrm{hen}$ and the average age of scavenging cockerels at first mating and pullets at first egg were 24.2 and 24.2 weeks, respectively. (Alemayehu G. 2017).

The birds scavenge in the vicinity of the homestead during daytime where they may be given cereal grains, cereal bran, broken grains and other house waste products as supplementary feed (Aklilu et al., 2007). Ethiopia is one of the few African countries with a significantly large population of chicken, estimated at 56.87 million (CSA, 2015). However, the number of chicken flocks per household in most Ethiopian rural communities is small; constituting an average of 7-10 mature chicken, 2-4 adult hens, a male bird (cock) and a number of growers of various ages (Tadelle and Ogle 2001). Alemu and Tadelle (1997) also reported that the local chicken in Ethiopia vary widely in body size, conformation, plumage color, comb type and feather cover. 


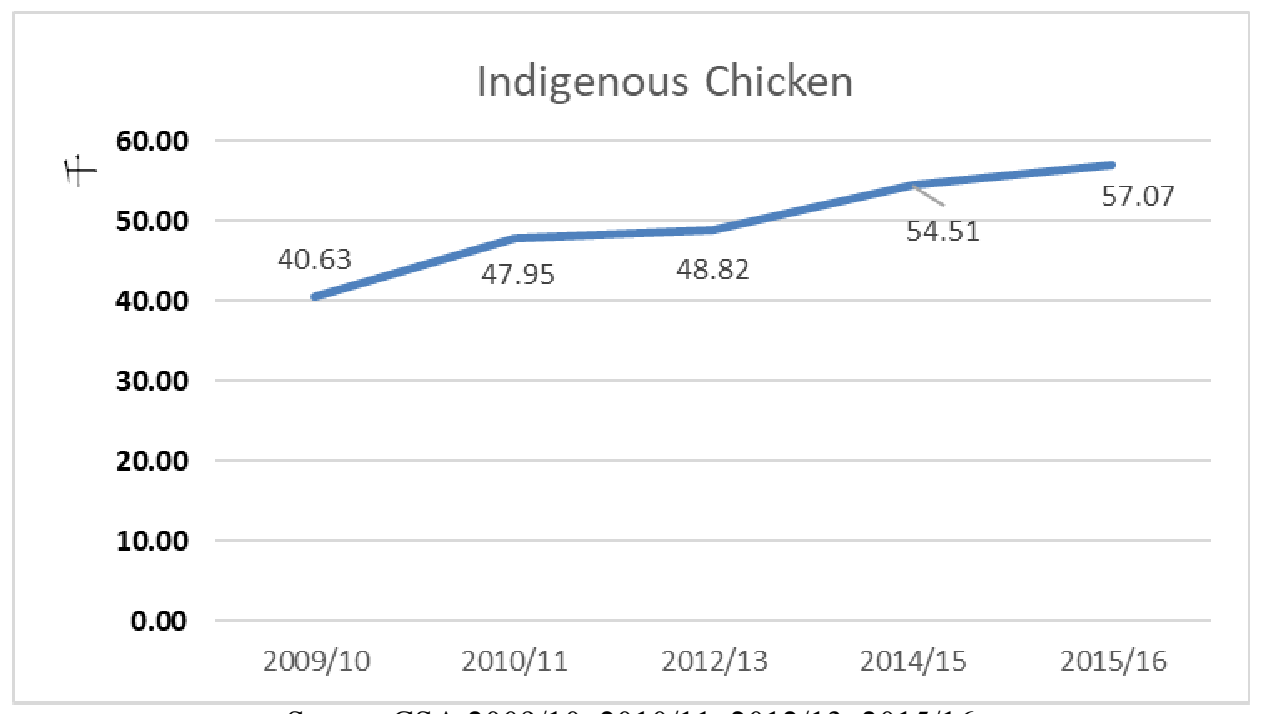

Source CSA,2009/10, 2010/11, 2012/13, 2015/16

\section{Exotic chicken}

No attempts have been recorded to evaluate the performance of exotic birds under local farmer conditions. The only serious on-station attempt carried out in Ethiopia was a comparative study of the performance of six different exotic breeds. Since 1950"s different breeds of exotic chickens such as, Layers breedAustralorp, New Hampshire, White Leghorns, Bovan Brown, Dominant D102, Lohmann silver, Lohman Brown Classic, Dominant Sussex D104, Novo Brown, dual purpose breed Rhode Island Red, Fayomi, Potchefstroom Koekoek, Red Barred D922, Novo Color, Lohman Dual and broiler breed Cobb 500, Hubbard Classic and Hubbard JV were imported to Ethiopia with the aim of improving poultry productivity and production (Alemayehu G. 2017). Now day two-layer breed TETRA-SL LL and TETRA-L SUPERB Parent stock imported from Hungary and under evaluation at Bishoftu (Debre Zeit) Agricultural research center. As a result, the estimate of total number of eggs produced during the year is about 106.57 million (CSA, 2015) which is less than other developing country. Currently there are about 5.4 million exotic and hybrid chickens, representing 9 percent of the total national poultry population.

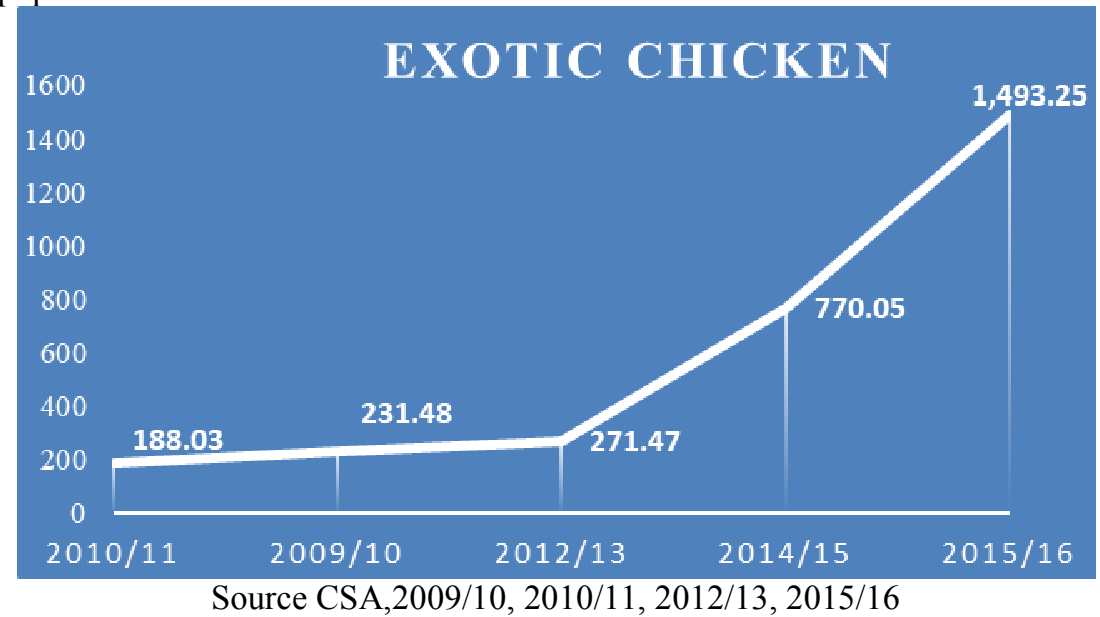

\section{Cross chickens}

Attempt has been made to introduce different exotic poultry breeds to small holder farming system of Ethiopia because of low performance of indigenous chicken.Farmers practiced control and uncontrolled mating system but majority households who practice uncontrolled mating $(81.1 \%)$ and control mating system $(18.9 \%)$. This indicates that the households have mix of chicken genotypes which creates favorable condition for unplanned indiscriminate crossbreeding among the variable genotypes (Alemayehu et. al. 2018a). 


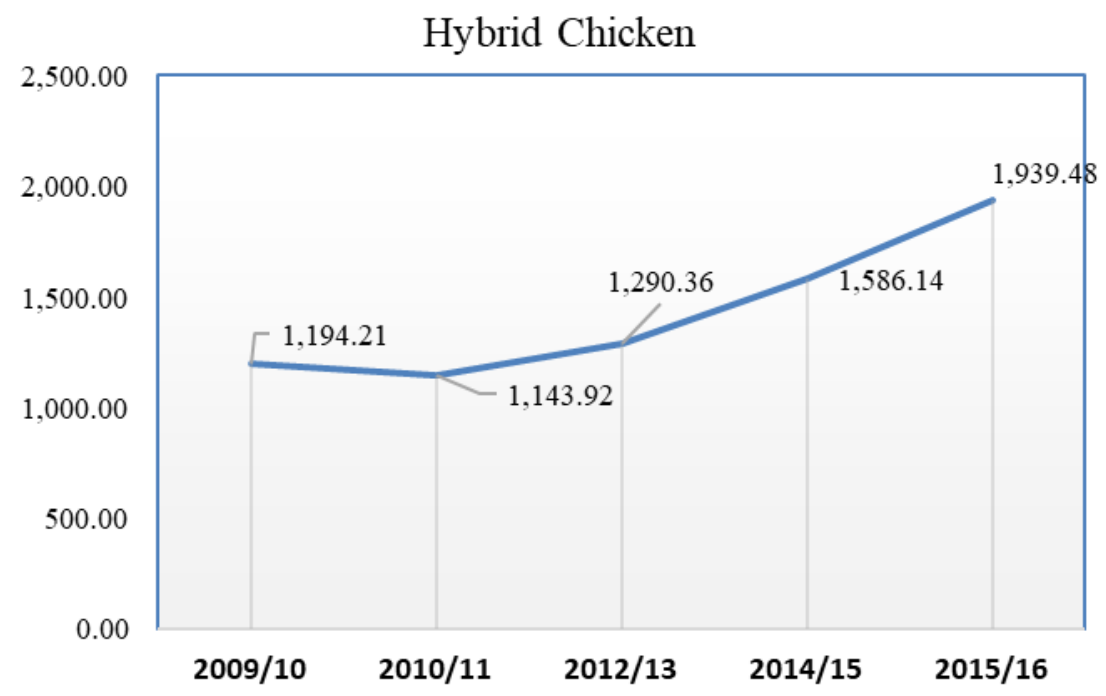

Source CSA,2009/10, 2010/11, 2012/13, 2015/16

Flock composition

Knowing of the flock composition and size of a given livestock breed is a prerequisite for designing, planning and implementation of appropriate breeding strategies and other management intervention. Generally higher flock size per households was recorded in October, November, December and January and average flock size of chickens per household was 5.6, 8 in lowland and midland agro-ecology, respectively and ranged from 2 to 20 chickens. (Alem. et al., 2013). Flock structure is described in terms of proportion of the different sex and age groups in the flock. According to Meseret (2010) the mean flock size per household was 6.23 chickens. In contrast, the mean flock size recorded in this study was lower than the mean flock size of 8.8 and 9.2 chickens/ household reported by Asefa (2007) for AwassaZuria and by Mekonnen (2007) for Dale woreda in Ethiopia, respectively.

Findings of several studies indicated that the average of flock size per household was 7.13 chicken and flock size varies between seasons mainly due to availability of feed, the occurrences of disease, the presence of predators as well as the economic status of the owners in Northwestern Ethiopia (Halima, 2007; 6.2 chicken in GommaWereda of Jimma zone (Meseret, 2010) and 13.1, 12.4 and 9.22 in Burie, Fogera and Dale woredas, respectively (Fessehaet al., 2010b). The indigenous, Exotic and crossbreed chicken flock size per house hold were 22.83, 0.96 and 1.57, respectively in the Western zone of Tigray region. (Shishay, 2014). The general indication is that the national average flock size of chicks, cockerels, pullet, hen, cocks, and total chicken per households were 5.3, 1.3, 1.7, 4, 1.5 and 11.1, respectively in Ethiopia.

Table 2. Flock composition

\begin{tabular}{lcccccc}
\hline \multirow{2}{*}{ Author's } & \multicolumn{7}{c}{ numbers of /household } \\
\cline { 2 - 7 } & Chicks & Cockerels & Pullet & Hen & Cock & $\begin{array}{c}\text { TT chicken } \\
\text { no/HH }\end{array}$ \\
\hline E.Moreda et.al 2013 & 0.932 & 0.3 & 0.6 & 2.49 & 0.79 & 4.86 \\
Getu and Birhanu. J . 2014 & 9.07 & 1.02 & 2.47 & 2.79 & 1.11 & 16.43 \\
Fiseha et.al 2014 & 2.5 & 0.36 & 0.69 & 2.79 & 0.61 & 13.7 \\
Dereje B. 2015 & 8.13 & - & - & 4 & 1.89 & 9.32 \\
Alemayehu et.al. 2018 & 7.15 & 4.67 & 3.94 & 5.89 & 2.29 & - \\
Endale Y.2017 & 3.71 & 0.33 & 0.8 & 5.95 & 1.99 & 11.22 \\
Average & $\mathbf{5 . 3}$ & $\mathbf{1 . 3}$ & $\mathbf{1 . 7}$ & $\mathbf{4}$ & $\mathbf{1 . 5}$ & $\mathbf{1 1 . 1}$ \\
\hline
\end{tabular}

Ownership and pattern and gender role

Chicken are reared by any members of a given family in both urban and rural areas of Ethiopian because they required less input (space, labour, capital and others). Overall women (53\%) accounted the maximum share in the offering feed for chickenfollowed by father and mother (13), hired person (7\%), all family member (9\%), mother with children \& father and mother with sole children female $(5 \%)$, mother and children female $(3 \%)$ mother with male children and sole female children equally $(2 \%)$ and motherwith children account $(1 \%)$. (Alemayehu G. 2017) 
A study conducted in Fogera woreda of Amhara regional state (Bogale, 2008) revealed that women human higher responsibility of providing feed and water (59.72\%). cleaning chicken house (62.5\%), Selling chicken $(56.95 \%)$ while men had the responsibility of shelter construction (63.89\%). According to Abubakar et al., (2007), in a study conducted on village chicken production in some parts of Nigeria and Cameroon, all gender categories are involved in chicken management, with children having the highest responsibility of housing the chicken at night and letting them out in the morning. Based on the result of the study, women own the majority of chicken $(52.7 \%)$ followed by children $(26.9 \%)$ and men $(20.4 \%)$ in Cameroon; unlike the situation in Nigeria, where the majority of the chickens are owned by men $(55.6 \%)$ followed by women $(38.9 \%)$ and 15 children $(11.1 \%)$. Halima (2007)) also reported that rural women in North-West Ethiopia are more responsible for chicken rearing in both male and female headed households, while men are responsible for crop cultivation and other off-farm activities.

\section{Feeding and feed resource}

All scavenging chicken producer practice supplementary feeding $(100 \%)$ from all type of feed, supplemented maize account (63\%) (Alemayehu. et. al. 2020). According to the results of this study, almost all of the respondents $(97.8 \%)$ reported to practice scavenging system with supplementary feeding. The result of this study was in agreement to that of Asefa (2007) and Mekonnen (2007) who reported $95-98 \%$ of the small scale household poultry producers in Awassa Zuria and Dale offer supplementary feeding to their chickens. The respondents of the current study also confirmed that the scavenging feed resource in Gomma Woreda consists of insect, grass, enset (Enseteventricosum), kitchen wastes, and harvest leftovers indicating that the village chicken production system is friendly with the environment.Poultry producers in Ethiopia are constantly complaining about the high cost and quality of poultry feed on the market. The quality of mixed feed used is generally poor and most formulations available do not have vitamin or mineral premixes (EIAR, 2016).

\section{Housing}

Majority (61.1\%) scavenging chicken producer construct separate house for their chicken from local available material while the rest $(38.9 \%)$ of them did not construct (Alemayehu et.al. 2020). Some research works also indicated that the mortality of scavenging birds reduced by improved housing. The finding of the survey carried out in village of Bangladesh by (Billah et al., 2013) indicate that poultry rearing and management practices were not satisfactory. Approximately $30 \%$ of farmers kept poultry in their village house, $46 \%$ in the earthen houses. $10 \%$ wooden house/ shed $8 \%$ wooden house or bamboo house and $6 \%$ concrete house. According to Nyoni and Mssika (2012), different form of housing structure were provided for the chickens $(96.7 \%)$ but $3 \%$ of chicken were roosted overnight in open space in Amatola Basin in Eastern Cape province of South Africa. Chicken house were constructed using wide range of materials. All structure was roofed with iron sheets. 8.6 \% of the structure had solid walls $14.8 \%$ had been wire mesh and $76.5 \%$ had a combination of iron sheet and wire mesh.

\section{Disease and predators}

Alemayehu G and Solomon A 2018 stated that diseases are the major constraints to the production of scavenging chickens which was rated (40\%) of the respondents followed by lack of chick management (16\%), lack feed $(9 \%)$, lack improved local chicken $(8 \%)$, absence of medicine $(6 \%)$, lack of regular vaccination $(5 \%)$, predator $(4 \%)$, lack of market chain and government favor chicken producers $(3 \%)$ and lack of capital, exotic chicken and weak extension (1\%).Among the disease Newcastle disease (ND), Infectious bursal disease (IBD), Marek's disease, Mycoplasmosis, Salmonellosis, Colibasilosis, Coccidiosis, Toxoplasmosis and Heliminthosis are poultry diseases with significant economic importance both in the family poultry production systems and intensive production systems in Ethiopia(FAO, 2019). ND is identified to be the most important disease in all production systems, being responsible for the largest proportion of morbidity and mortality in all parts of the country (Desalegn, 2015).

\section{Challenges and opportunities of chicken production}

FAO 2019 state chicken production challenges were poorly functioning farmers' organizations, Most potential investors tend to be risk averse and incline towards adopting short term investment strategies (potential investors are unlikely to make large long-term, financial investments unless they can achieve an adequate return on their investment), low level of education among primary producers, lack of feed quality control., inadequate availability of credit services, inadequate availability of water and electricity, poor coordination in the value chains: links among input suppliers, service providers, producers, and actors in the marketing channel are poorly coordinated, fluctuation in demand (especially as demand declines drastically during the Orthodox, Christians' fasting periods). Another constraint of chicken production under intensive management in Tigray were lack of knowledge to prepare mixed feed, the high price of mixed feed, unavailability of commercial feed in nearby area and cost of feed ingredients (Tadesse et al., 2017). 
The majorityscavenging chicken producers whereas (58\%) of the household hasnot discussed about their chicken productionit might be because of the development agent they were focus only on crop production, assigned inthe area were focus only on crop production (Alemayehu et.al. 2018a).Chicken have a short generation interval and a high rate of productivity. They can also be transported with ease to different areas and are relatively affordable and consumed by the rural people as compared with other farm animals such as cattle and small ruminants. Chickens also play a complementary role in relation to other crop-livestock activities. Indigenous chickens are good scavengers as well as foragers and have high levels of disease tolerance, possess good maternal qualities and are adapted to harsh conditions and poor-quality feeds as compared to the exotic breeds.

\section{Marketing systems of village chicken and egg in Ethiopia}

In Ethiopia selling of chickens and eggs is one of the functions of keeping free-range chickens by smallholder farmers. Village birds and eggs were taken by producer farmers to the local and urban markets and sold to traders (collectors) or directly to consumers depending on the location of the farm dwelling. Aklilu, (2007) reported that market access was low with increased distance to the market for poorer households. According to (Assefa, 2000; Halima, 2007), small holder chicken owner farmers found in different parts of Ethiopia sell chicken and eggs for the following objectives: to purchase food items, to cover school fees, grain milling services, purchase improved seeds and adjust the flock size. (Tadelle et al., 2001) also reported that few chicken owner farmers, in central highlands of Ethiopia, exchange their free-range chickens for food and household items.

\section{Egg production}

The annual egg production performance of local hen under farmers' management condition was found to be 60 egg/hen ranging from 24-112 egg in Bure district North West Ethiopia (Fisseha, 2009). Meseret (2010) also report that the mean annual egg production of the indigenous local hens of Gomma woreda was 43.8 egg/year/hen, which is comparable result to the reported ranges of 18-57 eggs in North West Ethiopia by (Halima, 2007) and 27-45 egg/year/hen in changni town, Awi administrative zones of Amhara region by (Ayalew \& Adane, 2013) but are lesser than the means of 60 eggs, 53 eggs and 55 eggs reported by Fesseha et al., (2010) in Bure, Fogera and Dale district of Ethiopia, respectively. The finding of another study revealed that average annual eggs/year/hen was $62.95 \pm 2.29,54.9 \pm 3.27$ and 51.44 \pm 1.40 in Wansho, Loka A and Dale woreda of Southern Ethiopia (Mekonnen, 2007) Another recent study's result revealed that the average eggs laid per year per hen under farmers' management condition was 65 eggs in Enebsei Sar Midir woreda of Eastern Gojjam (Yitbarek \& Zewudu, 2013)

Evaluation of the external and internal quality of chicken eggs is important because of consumer preferences for better quality eggs. Yolk color is a key factor in any consumer survey relating egg quality (Okeudo et al., 2003). It is generally agreed that all characteristics of egg quality have a genetic basis. Egg quality is the more important price contributing factor in table and hatching eggs. Therefore, the economic success of a laying flock solely depends on the total number of quality eggs produced. Quality of chicken eggs may vary due to several factors like rearing, temperature, relative humidity and season.

Table.3. Chicken production and productivity

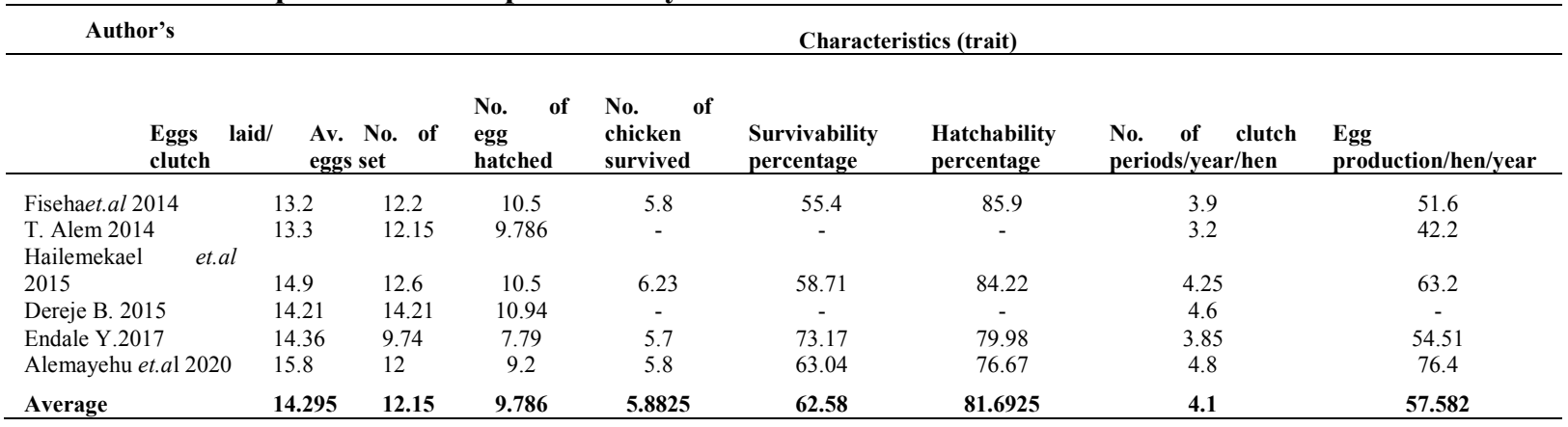

\section{Conclusion}

Chicken production system in Ethiopia were classified based on the situation/dynamic happen in the country. The current classification industrial and integrated/medium- and large-scale intensive systems and family poultry production systems (small-scale intensive, semi-intensive, extensive scavenging and small-extensive scavenging). Majority Ethiopian farmer engaged small extensive scavenging system, all scavenging chicken producer practice supplementary feeding (100\%) from all type of feed, supplemented maize account $(63 \%)$ which source of full of energy, so it needs incorporated protein source feed. To reduce cost of chicken feed government, have to focus increase the major feed ingredient in the country 
To tackle the chicken production in Ethiopian government,participate toshift small extensive scavenging to small-scale intensive or/and semi-intensiveor/and extensive scavenging by availing need in put like building skill, breed, vaccine veterinary service. Also, government encourage synthetics development institute which help to produce breed for farmer side by side for sustainable grow economy plant grandparent chicken farm in Ethiopia.

\section{Reference}

Aberra Melesse, Tegene Negesse and Werkinesh Tiruneh. 2011. Effects of feeding Moringa stenopetala leaf meal on nutrient intake and growth performance of Rhode Island Red chicks under tropical climate. Tropical and Subtropical Agro ecosystems, Journal. Vol 14 No 2

Abubakar, M., Ambali, A. and Tamjdo, T. 2007. Rural chicken production: Effects of gender on ownership, and management responsibilities in some parts of Nigeria and Cameroon. International Journal of Poultry Science, 6 (6):413-416.

Aklilu Hailemichael Asgedom. 2007. Village poultry in Ethiopia Socio-technical analysis and learning with farmers. Ph.D Thesis. Wageningen University, Wageningen, the Netherlands.

Alem Tadesse and Yayneshet Tesfay. 2013. Flock dynamics and composition of rural chickens in lowland and midland agro-ecological zones of central Tigray, North Ethiopia.

Alemayehu Guteta. 2017. Characterization of scavenging and intensive chicken production and marketing system in Lume district, East Shoa Zone, Oromia region state, Ethiopia M.Sc Thesis Haramaya University, Dire Dawa. Vol. 11(1), pp. 8-20, January-March 2020.

Alemayehu Guteta and Solomon Abegaz. 2018. Chicken Production Constraints in Lume District, East Shoa Zone, Oromia Region State, Ethiopia. World Journal of Agricultural Sciences 14 (5): 170-179, 2018.

Alemayehu Guteta \& Misba Alewi. 2018. Farmers Breeding Practice \& Traits of Economic Importance for Indigenous Chicken in Lume District, Oromia regional State, EthiopiaVolume 18 Issue 8 Version 1.0 Year 2018.

Alemayehu Guteta and Negasi Ameha. 2020.Characterization of scavenging and intensive chicken production system in Lume District, East Showa Zone, Oromia Regional State, Ethiopia, International Journal of Livestock Production, Vol. 11(1), pp. 8-20, January-March 2020.

Asefa, T. 2007. Poultry management practices and on farm performance evaluation of Rhode Island Red (RIR), Fayoumi and local chicken in Umbullo Wachu watershed.

Alemu Yami and Tadele Dessie. 1997. The Status of Poultry Research and Development in Ethiopia, Research Bulletin No.4. Poultry Commodity Research Program Debre Zeit Agricultural Research Center, Alemaya University of Agriculture, Ethiopia. $62 \mathrm{p}$.

Bogale, K .2008. In situ Characterization of local eco-type for functional traits and production system in fogera woreda, Amhara regional state. MSc. Haramaya Univesity, Haramaya, Ethiopia.

Billah, S.M., Nargis, F., Hossain, M.E.,Howlider, M.A.R \& Lee, S. H. 2013. Family poultry production and consumption pattern in selected households of Bangladesh. Journal of Agricultural Extension and rural development, 5(4); 62-69.

CSA (Central Statistics Authority). 2015. Agricultural sample survey 2014-2015. Survey on livestock and livestock characteristics, Vol. II. Statistical Bulletin No. 446. Addis Ababa, Ethiopia.

CSA (Central Statistical Authority) .2013. Agricultural sample survey. Sample Survey on livestock and livestock characteristics. The Federal Democratic Republic of Ethiopia, Private Peasant Holdings, Statistical Bulletin 570 Central Statistical Authority (CSA) Addis Ababa Ethiopia April 2013.

CSA (Central Statistical Authority). 2016. Federal Democratic Republic of Ethiopia Central Statistical Agency Agricultural Sample Survey 2016/17 [2009 E.C] Volume II. Survey on Livestock and Livestock Characteristics. 573 Statistical Bulletin. Addis Ababa, Ethiopia.

CSA Central Statistical Authority. 2017. Survey on livestock and livestock characteristics, Agricultural sample survey 2016/17 (2009 E.C.). Statistical Bulletin No.585, Vol. II. Addis Ababa.

EIAR (Ethiopian Institute of Agricultural Research). 2016. National Poultry Research Commodity Strategy (2016-2030), EIAR.

FAO (Food and Agriculture Organization of the United State Nations). 2009. A review of the current poultry disease control strategies in smallholder poultry production system and local poultry population in Uganda. Prepared by Terence Odaoch Amoki, Clovice Kankya ,Eunice L Kyomugisha, Danis K. Byarugaba, Nicoline de Haan and Karin Schwabenbauer. AHBL-Promoting strategies for presentation and control of H PAI. Rome.

FAO (Food and Agriculture Organization of the United State Nations). 2010. Chicken genetic resources used in smallholder production systems and opportunities for their development, by P. Sørensen. FAO Smallholder Poultry Production Paper No. 5. Rome.

FAO (Food and Agricultural Organization of the United State Nations). 2007. Poultry sector country review, Animal Production and Health Division, Emergency center for trans-boundary animal diseases socio 
economics, production and biodiversity unit, Food and Agriculture Organization of the United, Nations, Rome., Italy. Avialable at ftp://ftp.fao.org/docrep/fao/011/ai320e/ai320e00.pdf.

FAO. (Food and Agricultural Organization of the United State Nations). 2019. Poultry Sector Ethiopia. FAO Animal Production and Health Livestock Country Reviews. No. 11. Rome.

Fisseha Moges, Aberra Mellesse and Tadelle Dessie. 2010. Assessment of village chicken production system and evaluation of the productive and reproductive performance of local chicken ecotype in Bure district, Northwest Ethiopia. African Journal of Agricultural Research. 5(13):1739-1748.

Fesseha Moges. 2009. Studies on production and marketing system of local chicken ecotypes in BureWoreda, North-West Amhara, M.Sc Thesis. Hawassa University, Hawassa.

Halima Hassen. 2007. Phenotypic and genetic characterization of indigenous chicken populations in North-West Ethiopia. Ph.D. Thesis. Submitted to the faculty of natural and agricultural sciences department of animal, wildlife and grassland Sciences. University of the Free State, Bloemfontein, South Africa.

Mekonnen Gebre Egizaber. 2007. Characterization of smallholder poultry production and marketing system of Dale, wonsho and loka abaya woredas of southern Ethiopia. MSc. Thesis presented to the School of Graduate Studies of Hawassa University.

Meseret Molla. 2010. Characterization of village chicken production and marketing system in Gomma woreda, Jimma zone, Ethiopia. M.Sc Thesis. Jimma University, Ethiopia.

Mengesha M. and Tsega W. 2011. Phenotypic and genotypic characteristics of indigenous chickens in Ethiopia: A review. African Journal Agriculture Research, 6(24): 5398-5404.

Misba Alawi and Melesse Aberra. 2011. Evaluating the growth performance of local kei chickens and their f1crosses with Rhode Island Red and Fayoumi breeds in watershed areas of guraghe administrative zone, Southern Ethiopia. MSc. Thesis. Hawassa University, Ethiopia.

Nyoni, N.M.B. \& Masika, P.J. 2012. Village chicken production practice in the Amatola basin of the Eastern Cape province, South Africa. Africa journal of agricultural Research Vol.7 (17), pp. 2647-2652. Available online at http://www.academic journals.org/AJAR DOI 10.589/AJAR11.1669 ISSN 1991-367X@2012 Academic journals.

Okeudo. N, Onwuchekwa. C and Okoli, I. 2003. Effect of oil treatment and length of storage on the internal quality, organoleptic attributes and microbial profile of chicken eggs. Tropical Animal Production, 6:63-70.

Samson L, Endalew B. 2010. Survey on Village Based Chicken Production and Utilization System in Mid Rift Valley of Oromia, Ethiopia. Global Vet., 5 (4): 198-203.

Shapiro, B.I., Gebru, G., Desta, S., Negassa, A., Nigussie, K., Aboset, G. and Mechal, H. 2015. Ethiopia livestock master plan. ILRI. Nairobi, Kenya: International Livestock Research Institute (ILRI).

Shishay Markos. 2014. Phenotypic characterization of local chicken ecotypes in Western zone of Tigray, Northern Ethiopia, MSc Thesis, Jimma university, Ethiopia.

Tadelle Dessie and Ogle B. 2001. Village Poultry Production System in the Central Highlands of Ethiopia. Tropical Animal Health and Production, 33, 521- 537.

Tadelle Dessie, C. Kijora and K.J. Peters. 2003. Indigenous chicken ecotypes in Ethiopia, Growth and feed utilization potential. International Journal of Poultry Science 2: pp 144-152.

Tadesse, H. F., M. G. Banu, T. Awalom, H. Tadelle, and G. T.Mawcha. 2017. Assessment of chicken feed, feeding managementand chicken productivity in intensive poultry farms at selectedfarms of three zones in Tigray region. J. Vet. Sci. Technol. 8:472.

Wilson, R. (2010): Poultry production and performance in the Federal Democratic Republic of Ethiopia. World's Poultry. Sci. J., 66.

Yitbark, M.B., \& Zewudu, A. 2013. Performance Evaluation of local chicken at Rnebsie Sar Midir Woreda Gojam, Ethiopia. Unique Research Journal of agricultural science, 1(2); 6-10. 